\title{
MAGE-A protein and MAGE-A 10 gene expressions in liver metastasis in patients with stomach cancer
}

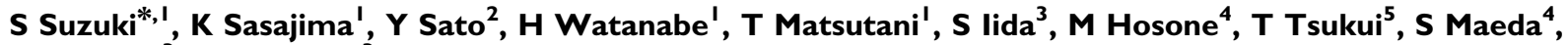 K Shimizu ${ }^{3}$ and $T$ Tajiri $^{3}$}

'Department of Surgery, Tama-Nagayama Hospital, Nippon Medical School, Tama, Tokyo, Japan; ${ }^{2}$ Department of Molecular Diagnostics, School of Allied Health Science, Kitasato University, Sagamihara, Kanagawa, Japan; ${ }^{3}$ Department of Surgery, Nippon Medical School, Bunkyo-Ku, Tokyo, Japan;

${ }^{4}$ Department of Pathology, Tama-Nagayama Hospital, Nippon Medical School, Tama, Tokyo, Japan; ${ }^{5}$ Department of Gastroenterology,

Tama-Nagayama Hospital, Nippon Medical School, Tama, Tokyo, Japan

Tumour samples from 7I patients with stomach cancer, 4 I patients with liver metastasis (group A) and I 5 patients each in stages IIIV (group B) and stage I (group C) without liver metastasis were analysed. MAGE-A protein expression was evaluated by immunohistochemistry using a $6 \mathrm{Cl}$ monoclonal antibody and MAGE-AIO mRNA expression was detected by highly sensitive in situ hybridisation using a CRNA probe. Expressions of MAGE-A protein and MAGE-A I0 mRNA in group A were detected in 65.9 and $80.5 \%$, respectively. Both protein and gene showed significantly higher expression in group $A$ than those in groups $B(6.7,26.7 \%)$ and $\mathrm{C}(0,0 \%)(P=0.0003, P=<0.000 \mathrm{I}$, respectively). MAGE-A 10 mRNA expression in liver metastasis was found in eight (88.9\%) out of nine patients. The concordant rate between MAGE-A family protein expression and MAGE-A I 0 mRNA expression in the primary sites was $81.7 \%(P<0.000 I)$. MAGE-AIO gene expression was associated with reduced survival duration. The results of this study suggest that MAGE-AIO is a possible target in active immunotherapy for advanced stomach cancer.

British Journal of Cancer (2008) 99, 350-356. doi:I0.1038/sj.bjc.6604476 www.bjcancer.com

Published online I July 2008

(c) 2008 Cancer Research UK

Keywords: MAGE-A protein; MAGE-AIO mRNA; highly sensitive in situ hybridisation; stomach cancer; liver metastasis; active immunotherapy

Stomach cancer is one of the most common worldwide malignant neoplasms (Dicken et al, 2005). Although its incidence is decreasing, it is the second most common cancer in Japan after lung cancer and contributes to the burden of cancer death (Inoue and Tsugane, 2005). The presence of distant metastasis is an independent prognostic factor (Siewert et al, 1998). In particular, patients with liver metastasis had shown a poor prognosis in spite of combined therapy (Sarela et al, 2006). Therefore, further study to understand the molecular changes associated with stomach cancer especially when tumour progresses needs to be undertaken to introduce treatment strategies. Furthermore, the mechanism of liver metastasis should be elucidated, as it may present a clue to predict and subsequently treat patients with liver metastasis.

It has been reported that MAGE-A family genes located at chromosome Xq28 are expressed in malignant tumours, whereas they are not expressed in adult tissue except the testis and placenta. Of the MAGE-A family, MAGE-A1, -A3, -A6 and -A10 encode tumour antigens recognised by autologous cytotoxic $\mathrm{T}$ cells (CTL) (De Plaen et al, 1994). A CTL clone that could lyse autologous melanoma cells significantly produced tumour necrosis factor on stimulation with HLA-A2 MAGE-A10-expressing cells (Huang et al, 1999). Only CTL recognising the antigenic peptide

*Correspondence: Dr S Suzuki, Department of Surgery, Tama-Nagayama Hospital, Nippon Medical School, I-7-I, Nagayama, Tama, Tokyo 206-85।2, Japan; E-mail: seij@nms.ac.jp

Revised 4 June 2008; accepted 4 June 2008; published online I July 2008 with high efficiency can lyse the tumour cells expressing the cancer/testis (CT) antigens. Thus, these antigens may be suitable targets for active immunotherapy in malignant tumours such as melanoma (Dutoit et al, 2001, 2002; Ayyoub et al, 2003).

In stomach cancer, MAGE-A protein expression was detected in only $15.8 \%$ of the samples, and correlated with lymph node metastasis, advanced stage of the disease and a worse prognosis (Jung et al, 2005). However, MAGE-A protein was expressed at lower levels in metastatic lymph nodes from stomach cancer than in the primary lesions (Sadanaga et al, 1999). The frequency of MAGE-A1,-A2 and -A3 gene expression was reported to be 41, 31 and $38 \%$ in the primary lesion, respectively (Inoue et al, 1995). About $74 \%$ of the tumours expressed at least one CT antigen, most frequently MAGE-A3, -A4 and NY-ESO-1. However, MAGE-A gene expression did not correlate with clinicopathologic findings of the tumours (Wang et al, 2004). MAGE-A10 expression was reported to be low in the primary lesion and had no correlation with the clinicopathology of the tumours (Li et al, 1997). There have been no reports on the expression of the MAGE-A10 gene in metastatic lesions in patients with stomach cancer.

In this study, the MAGE-A family protein expression was detected by immunohistochemistry using the mouse monoclonal antibody $6 \mathrm{C} 1$, which cross-reacted with MAGE-A1, -A3, -A4, -A6, -A10 and -A12 (Rimoldi et al, 2000). Furthermore, to clarify the distribution of MAGE-A10 mRNA expression in stomach cancer tissue, the highly sensitive in situ hybridisation (ISH) using cRNA probes that enabled us to detect even the low-copy gene expression in clinical samples was performed. Our objective was to assess the 
significance of MAGE-A protein and MAGE-A10 gene expressions in the progression of stomach cancer and to elucidate suitable patients for active immunotherapy using MAGE-A10 peptide.

\section{MATERIALS AND METHODS}

\section{Tumour samples}

Formalin-fixed and paraffin-embedded tissues were obtained from a series of 71 patients who had undergone gastrectomy for stomach cancer at the Tama-Nagayama Hospital, Nippon Medical School. In five unresectable cases, biopsy specimens were used. The patients were divided into three groups. Group A consisted of 41 patients with liver metastasis occurring within 3 years after the operation: synchronous metastasis (stage IV) in 23 cases and metachronous metastasis (stages I-IV) in 18 cases. In group A, nine hepatectomised specimens (synchronous in six, metachronous in three) were used, in addition to the primary sites. Groups $B$ and C consisted of 15 patients each with stages II - IV and stage I without liver metastasis. The final stage and histopathologic findings are defined according to the Japanese Classification of Gastric Carcinoma (Japanese Gastric Cancer Association, 1998). Patients' characteristics and pathologic findings are listed in Table 1. Informed consent was obtained from all patients. The study was approved by the Institutional Review Board of TamaNagayama Hospital, Nippon Medical School.

\section{Immunohistochemistry}

The sections were deparaffinised in xylene and hydrated through descending ethanol series and water. Antigen retrieval was performed with the DAKO Target Retrieval Solution (DAKO, Glostrup, Denmark) for $40 \mathrm{~min}$ at $98^{\circ} \mathrm{C}$. Endogenous peroxidase blocking was performed with $0.3 \%$ hydrogen peroxide in methanol. After incubation with the mouse monoclonal antiMAGE-A antibody 6C1 (Neo-Markers, Fremont, CA, USA) for 30 min at room temperature, DAKO ENVISION Plus detection was applied for $30 \mathrm{~min}$ at room temperature. Then, diaminobenzidine was dropped as a chromogen. The slides were counterstained with haematoxylin and mounted.

\section{In situ hybridisation}

Preparation of the cRNA probes Total RNA was extracted from LCN1 cells derived from neuroendocrine carcinoma of the lung

Table I Patients' characteristics in each group

\begin{tabular}{|c|c|c|c|}
\hline & Group A & Group B & Group C \\
\hline \multicolumn{4}{|l|}{ Age (years) } \\
\hline Median (range) & $70(47-90)$ & $63(43-77)$ & $66(30-77)$ \\
\hline \multicolumn{4}{|l|}{ Gender } \\
\hline Male/female & $37 / 4$ & $11 / 4$ & $10 / 5$ \\
\hline \multicolumn{4}{|l|}{ Stage } \\
\hline IA & । & - & 15 \\
\hline IB & I & - & 0 \\
\hline$\|$ & 5 & 8 & - \\
\hline$\| I A$ & 4 & 4 & - \\
\hline IIIB & 6 & 2 & - \\
\hline IV & $24(23)^{a}$ & I & - \\
\hline \multicolumn{4}{|l|}{ Histology } \\
\hline Differentiated ${ }^{\mathrm{b}}$ & 25 & 4 & 8 \\
\hline Undifferentiated $^{c}$ & 16 & | | & 7 \\
\hline
\end{tabular}

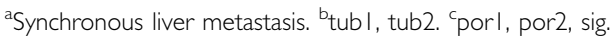

(Jiang et al, 2004) with Isogen (Nippon Gene, Tokyo, Japan) according to the manufacturer's instructions and reverse transcribed with the First Strand cDNA Synthesis Kit for RT-PCR (Roche Diagnostics, Mannheim, Germany). Primer sequences used in this study against MAGE-A10 mRNA have been described previously (Peng et al, 2005). Digoxigenin (DIG)-labelled sense and antisense cRNA probes were generated by T7 RNA polymerase promoter region-tailed PCR followed by in vitro transcription with T7 RNA polymerase using a DIG in vitro transcription kit (Roche Diagnostics) described in detail previously by Tanizaki et al (2006).

Highly sensitive in situ hybridisation The ISH was carried out as described previously (Yoshikawa et al, 2007). In brief, deparaffinised $4-\mu \mathrm{m}$-thick sections were treated with $10 \mu \mathrm{g} \mathrm{ml}^{-1}$ proteinase $\mathrm{K}$ (Roche Diagnostics) for $20 \mathrm{~min}$ at $37^{\circ} \mathrm{C}$. The sections were postfixed in $4 \%$ paraformaldehyde and treated with $0.2 \mathrm{~N} \mathrm{HCl}$ and $0.25 \%$ acetic anhydride in $0.1 \mathrm{M}$ tri-ethanol amine $(\mathrm{pH} 8.0)$ for $10 \mathrm{~min}$ each. After treatment with $3 \%$ hydrogen peroxide for $60 \mathrm{~min}$, the sections were dehydrated and air-dried. A $50 \mu$ l portion of the hybridisation mixture (mRNA In-situ Hybridization Solution) (DAKO) with $10 \mathrm{ng}$ sense or antisense cRNA probe was loaded onto each section and hybridised for $16-18 \mathrm{~h}$ at $50^{\circ} \mathrm{C}$. After hybridisation, the sections were washed in $2 \times$ standard sodium citrate (SSC) $/ 50 \%$ formamide for $30 \mathrm{~min}$ at $55^{\circ} \mathrm{C}$ and treated with $10 \mu \mathrm{g} \mathrm{ml}^{-1}$ RNase A (Roche Diagnostics) for $30 \mathrm{~min}$ at $37^{\circ} \mathrm{C}$ and stringently washed with $2 \times$ SSC, $0.2 \times$ SSC and $0.1 \times$ SSC for $20 \mathrm{~min}$ each at $55^{\circ} \mathrm{C}$. After being placed into $0.01 \mathrm{M}$ Tris- $\mathrm{HCl} \mathrm{pH}$ $7.5,0.3 \mathrm{M} \mathrm{NaCl}$ and $0.1 \%$ Tween 20 (TBS-2T) three times for $5 \mathrm{~min}$ each, and in $0.5 \%$ casein $/ 0.01 \mathrm{M}$ Tris- $\mathrm{HCl} \mathrm{pH} 7.5$ and $0.15 \mathrm{M} \mathrm{NaCl}$ for $10 \mathrm{~min}$, the sections were reacted with 400 times diluted horseradish peroxidase (HRP)-conjugated rabbit anti-DIG Fab' fragmented polyclonal antibody (DAKO), $0.07 \mu \mathrm{moll}^{-1}$ biotinylated tyramide and 500 times diluted HRP-conjugated streptavidin (DAKO) for $15 \mathrm{~min}$ each. Finally, the sections were visualised with DAB solution (DAB Substrate Kit) (DAKO) and counterstained with Mayer's haematoxylin. Thereafter, sections were mounted with Pristine Mount (Invitrogen, Carlsbad, CA, USA).

\section{Scoring of immunohistochemistry and in situ hybridisation}

Evaluation of tumour cells in each sample was scored as $0,1,2$ or 3 , corresponding to absent, weak, moderate or intense staining, respectively. The intensity of the cells scoring moderate or higher was judged as positive. The tissues consisting of more than $30 \%$ positive tumour cells were considered significant.

\section{Statistical analysis}

Fisher's exact test, Kaplan-Meier survival analysis and log-rank test for univariate analysis were performed using the Statview 5.0 software (Abacus System, Berkeley, CA, USA). $P$-values $<0.05$ were considered significant.

\section{RESULTS}

MAGE-A protein and MAGE-A10 mRNA expression in the primary lesion

The incidence of MAGE-A protein expression was $65.9 \%$ (27 cases) in group A, 6.7\% ( 1 case) in group B and $0 \%$ in group C. Although both nucleus and cytoplasm were stained against $6 \mathrm{C} 1$ in most of the cases, in some cases the nucleus was dominantly stained (Figure 1A and 1B). No positive staining was found in any of the non-cancerous tissues (Figure 1C). Of 28 cases positive for $6 \mathrm{C} 1$, the distribution of positively stained cells showed a diffuse pattern in $67.9 \%$ (19 cases) and a focal pattern in $32.1 \%$ (9 cases). The 
A

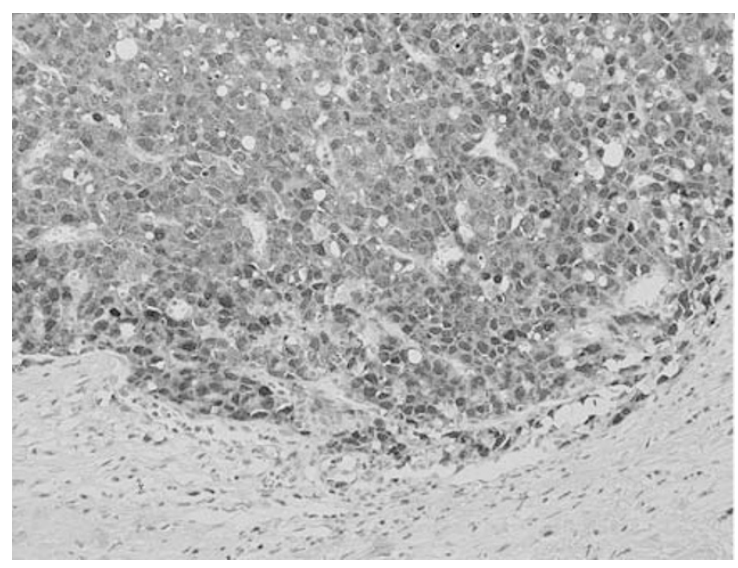

C

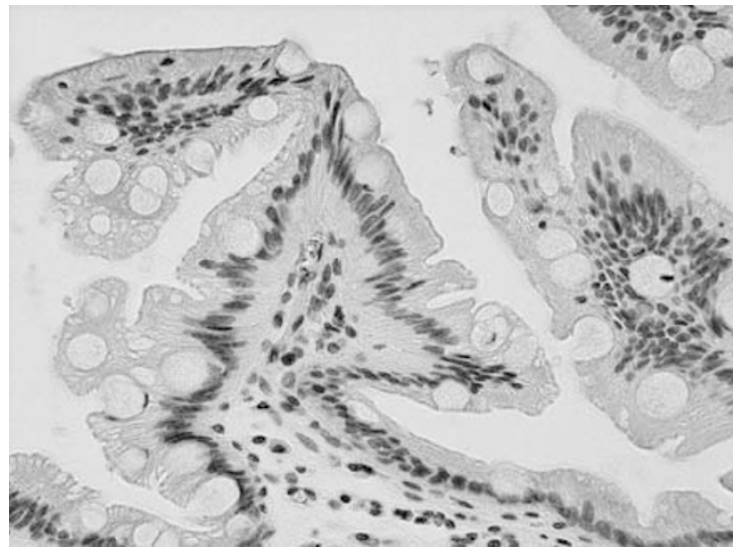

E

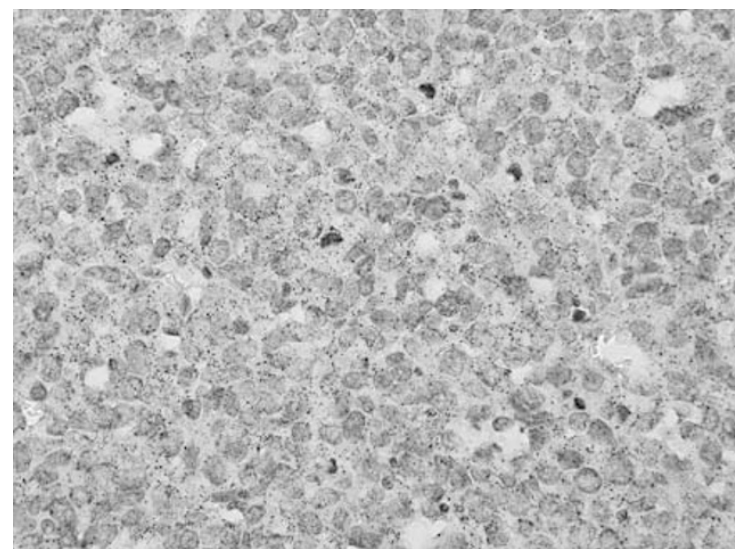

B

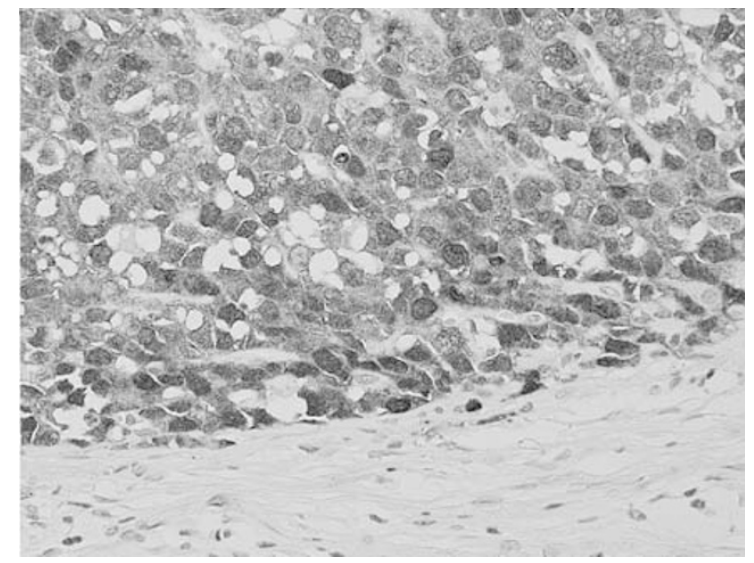

D

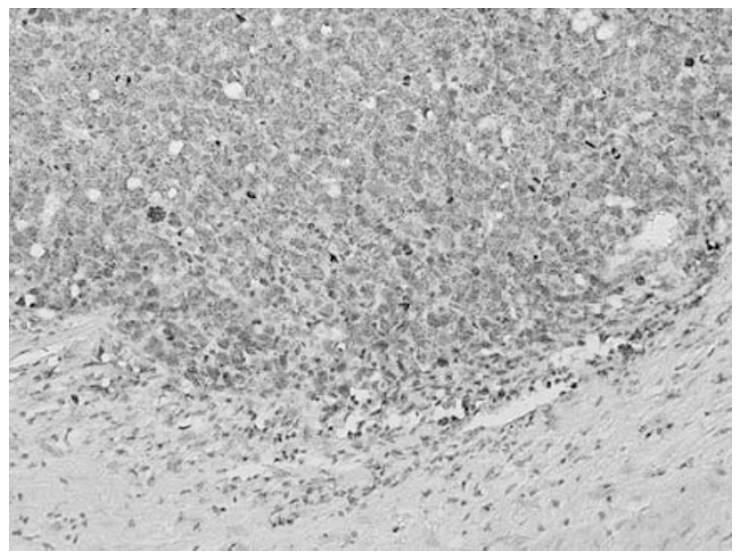

$\mathbf{F}$

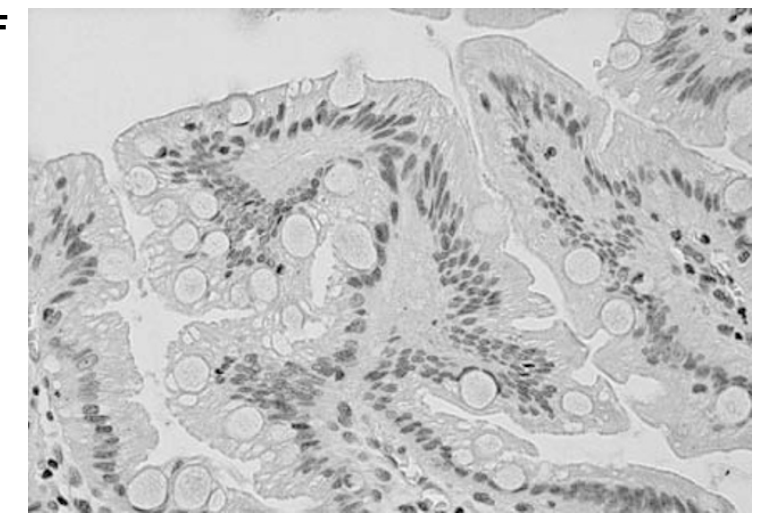

Figure I A case with synchronous liver metastasis (case 13). At the primary site, (A) MAGE family proteins were observed in the nuclei of tumour cells $(\times 80)$. (B) High-power view of $(\mathbf{A})$. They were dominantly and homogeneously localised in the nuclei of tumour cells $(\times 200)$. (C) At the normal gastric mucosa, MAGE family proteins were not observed $(\times 80)$. (D) MAGE-AI0 mRNA signals were coincidently observed in MAGE family protein-positive tumour cells $(\times 80)$. (E) High-power view of $(\mathbf{D})$. They were abundant in the cytoplasm of tumour cells $(\times 200)$. (F) At the normal gastric mucosa, MAGE-AI0 mRNA signals were not found $(\times 80)$.

incidence of MAGE-A protein in group A was significantly higher than that in groups $B$ and $C(P=0.0001$ and $P<0.0001$, respectively).

The incidence of MAGE-A10 mRNA expression was 80.5\% (33 cases) in group A, 26.7\% (4 cases) in group B and $0 \%$ (none) in group C. No positive staining was observed with the sense cRNA probe. Figure $1 \mathrm{D}$ and $1 \mathrm{E}$ presents a case with MAGE-A10 mRNA expression in the primary site (case 13). No positive staining was observed in any of the non-cancerous tissues (Figure 1F). Further, no positive staining was observed with the sense cRNA probe.
Table 2 Correlation of $6 \mathrm{Cl}$ and MAGE-A 10 mRNA expression and rate of concordance in each group

\begin{tabular}{lccc}
\hline & Group A & Group B & Group C \\
\hline 6CI (+)/MAGE-AI0 (+) & 25 & 1 & 0 \\
6CI (+)/MAGE-AI0 (-) & 2 & 0 & 0 \\
6Cl (-)/MAGE-AI0 (+) & 8 & 3 & 0 \\
6Cl (-)/MAGE-AI0 (-) & 6 & 11 & 15 \\
Total & 41 & 15 & 15 \\
Rate of concordance (\%) & 75.6 & 80 & 100 \\
\hline
\end{tabular}


Significant differences were detected between group A and groups $\mathrm{B}$ and $\mathrm{C}(P=0.0003$ and $P<0.0001$, respectively $)$. MAGE-A10 mRNA expression with liver metastasis was more frequent in $87.0 \%$ of synchronous metastasis compared with $72.2 \%$ of metachronous metastasis. However, no statistical significance was observed. The association of the expression of MAGE-A protein and MAGE-A10 mRNA is listed in Table 2. Of 37 cases with MAGE-A10 mRNA expression, 70.3\% (26 cases) were positive for MAGE-A protein. The rates of concordance between MAGE-A protein expression and MAGE-A10 mRNA expression were $75.6 \%$ in group A, $80.0 \%$ in group $B$ and $100 \%$ in group C. Totally, the rate of concordance was $81.7 \%(P<0.0001)$.

\section{MAGE-A protein expression and MAGE-A10 mRNA expression in liver metastasis}

In nine cases of hepatectomy or liver biopsy for metastatic lesions, positive expressions were detected in seven (77.8\%) for MAGE-A protein and eight $(88.9 \%)$ for MAGE-A10 mRNA (Table 3). Two cases in the positive MAGE-A10 mRNA group were negative for 6C1 expression (cases 16 and 21). Both MAGE-A protein and MAGE-A10 mRNA expressions in hepatic tissue with a synchronous liver metastasis (case 7) are shown in Figure 2.

\section{MAGE-A protein expression and MAGE-A10 mRNA expression in alpha fetoprotein-producing stomach cancer}

Of five cases with alpha fetoprotein (AFP) producing stomach cancer proved by serum concentration and immunohistochemistry,
MAGE-A protein expression and MAGE-A10 mRNA expression were found in three cases $(60.0 \%)$ and five cases $(100 \%)$, respectively. Five cases of positive MAGE-A10 mRNA expression were intensely and diffusely stained in the tumour cells. Figure 1 presents a case with AFP-producing stomach cancer expressing MAGE-A protein and MAGE-A10 mRNA (case 13).

\section{Survival analysis}

Kaplan-Meier analysis revealed that group A had significantly shorter survival duration than groups $\mathrm{B}$ and $\mathrm{C}(P<0.0001$, each). A

Table 3 Expression of $6 \mathrm{Cl}$ and MAGE-AIO mRNA in hepatectomised patients

\begin{tabular}{|c|c|c|c|c|c|}
\hline \multirow[b]{2}{*}{ Case } & & \multicolumn{2}{|c|}{ Primary } & \multicolumn{2}{|c|}{ Liver } \\
\hline & & $6 \mathrm{Cl}$ & MAGE-AIO & $6 \mathrm{Cl}$ & MAGE-AIO \\
\hline I & $M$ & + & + & + & + \\
\hline 2 & $M$ & - & + & - & + \\
\hline 7 & $S$ & + & + & + & + \\
\hline 12 & $\mathrm{~S}$ & + & + & + & + \\
\hline 16 & $M$ & + & + & + & - \\
\hline 17 & $\mathrm{~S}$ & + & + & + & + \\
\hline 21 & $\mathrm{~S}$ & - & + & + & + \\
\hline 28 & $\mathrm{~S}$ & + & + & + & + \\
\hline 41 & $S$ & - & + & - & + \\
\hline
\end{tabular}

$\mathrm{M}=$ metachronous liver metastasis; $\mathrm{S}=$ synchronous liver metastasis.
A

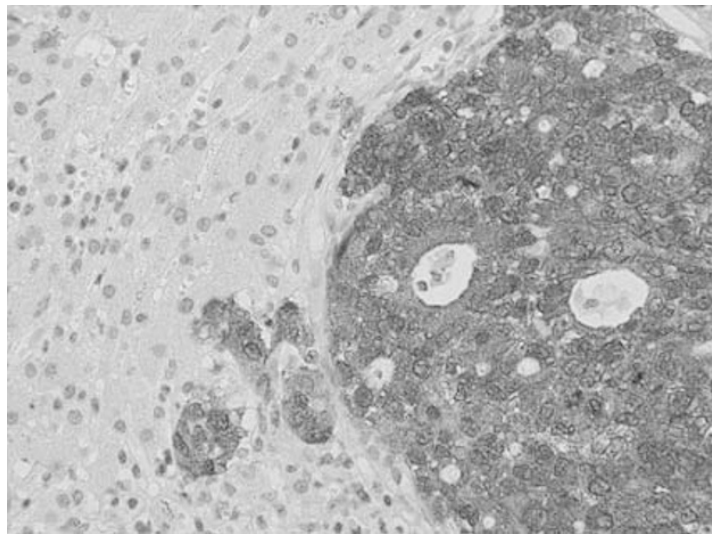

C

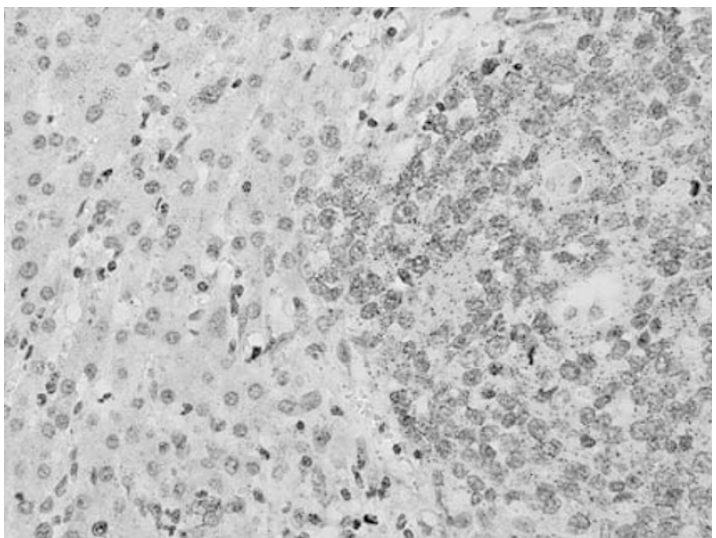

B

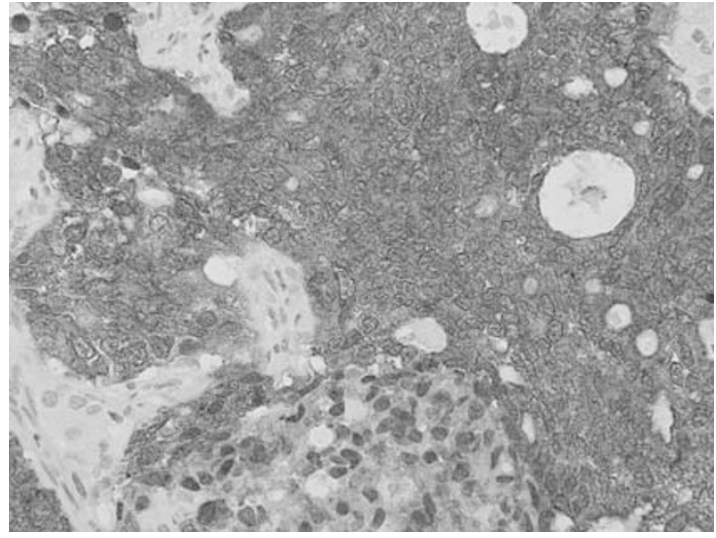

D

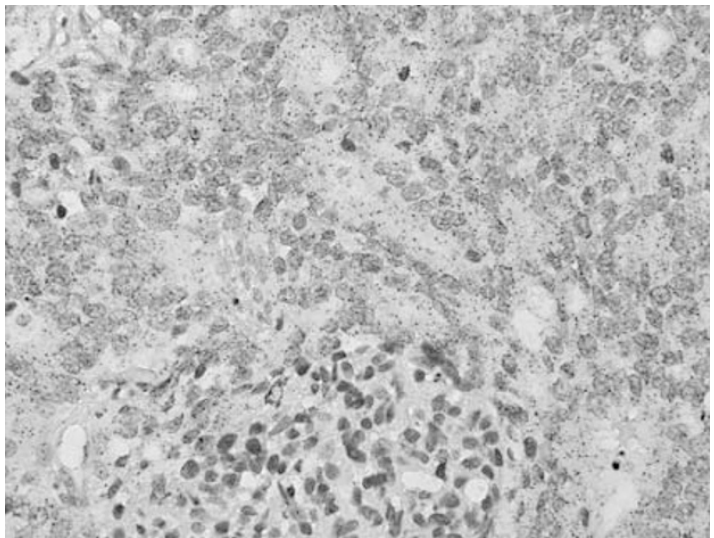

Figure 2 A case with synchronous hepatic metastasis (case 7). At the hepatic metastasis, (A) MAGE family proteins were observed in both nuclei and cytoplasm of tumour cells. No positive staining was observed in adjacent normal liver tissues $(\times 80)$. (B) High-power view of $(\mathbf{A})$. Intense and homogeneous staining was observed in almost all tumour cells $(\times 200)$. (C) MAGE-A I 0 mRNA signals were coincidently observed in MAGE family proteinpositive tumour cells $(\times 80)$. (D) High-power view of $(\mathbf{C})$. They were abundant in the cytoplasm of tumour cells $(\times 200)$. 

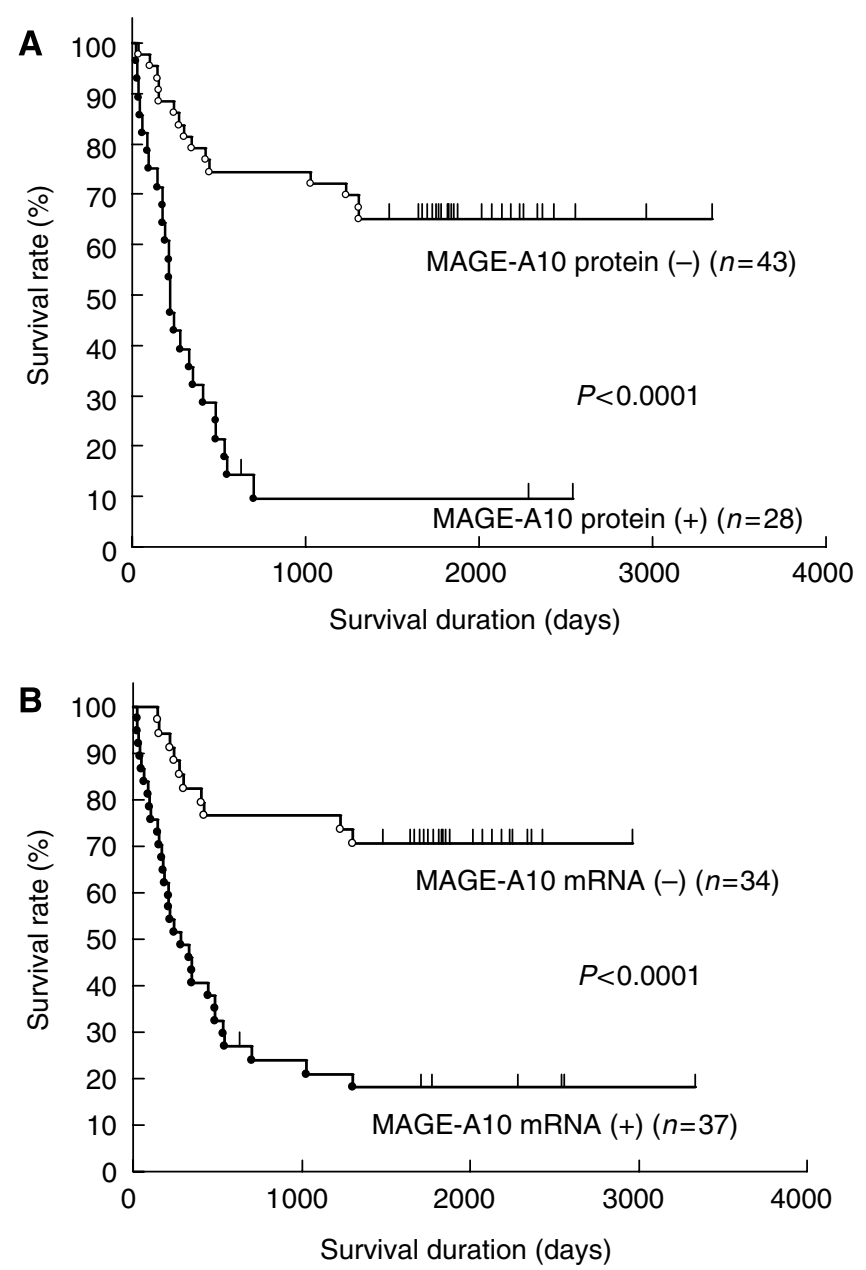

Figure 3 Relationship between MAGE-A family protein $(\mathbf{A})$ and MAGEA 10 mRNA (B) expression and survival duration in all cases.

5-year survival rate was $6 \%$ in group A, $87 \%$ in group B and $100 \%$ in group C. Patients with MAGE-A protein and MAGE-A10 gene expression had poor outcome $(P<0.0001$, each) (Figure $3 \mathrm{~A}$ and $3 \mathrm{~B})$. Only three patients with MAGE-A10 gene expression survived more than 5 years.

\section{DISCUSSION}

In this study, we have analysed MAGE-A protein expression by immunohistochemistry using a monoclonal 6C1 antibody and MAGE-A10 gene expression by ISH using a cRNA probe in stomach cancer patients with and without liver metastasis. This is the first report, to the best of our knowledge, that provides a new insight into the expressions of the MAGE-A protein and MAGEA10 gene in patients with stomach cancer. The expression of both was significantly higher in patients with liver metastasis than in patients without liver metastasis. We also found that the MAGE-A10 gene was frequently expressed in the primary and metastatic lesions and was associated with a poor outcome.

In stomach cancer, MAGE-A protein expression was associated with the stage and a worse prognosis, but not with distant organ metastasis (Jung et al, 2005). MAGE-A1 gene expression has been reported to be observed in the early stage of stomach cancer (Katano et al, 1997). However, Honda et al (2004) reported that demethylation in MAGE-A1 and -A3 promoters was much higher in advanced clinical stages. Distant metastasis is an independent

prognostic factor in patients who have undergone surgical resection (Siewert et al, 1998). Recurrence after complete resection of stomach cancer occurs within 2 years and is fatal. Furthermore, there was recurrence in distant sites in half of the patients and liver metastasis was most frequent (D'Angelica et al, 2004). In this study, most cases with both synchronous and metachronous liver metastasis expressed the MAGE-A protein and MAGE-A10 gene in both primary and metastatic lesions. Although the total number was small in our series, two stage I patients who developed metachronous liver metastasis expressed MAGE-A10 mRNA in the primary lesions. It might be a predictive marker for metachronous liver metastasis even in low-stage stomach cancers. On the other hand, Alves et al (2007) reported that MAGE-A10 mRNA expression was found in only 2 and $0 \%$ of the cases of primary lesion and liver metastasis in colon cancer, respectively. We assume that this discrepancy might be due to the differences in the regulation of MAGE-A gene expression and the clinical outcome of liver metastasis between these organs. These results emphasised that expression of the MAGE-A genes might play an important role in the progression of stomach cancer.

AFP-producing stomach cancer is highly malignant and has a poor prognosis as the recurrent rate following curative resection is high (Adachi et al, 2003). Amemiya et al (2005) reported that c-Met overexpression was frequently detected in AFP-producing stomach cancer, whereas Kataoka et al (2001) reported that the absence of ATBF1 gene expression is responsible for AFP gene expression. Recently, Cho et al (2007) reported that five of the eight cancers with AFP expression showed genetic alterations of the ATBF1 gene. In our study, all AFP-producing tumours intensely expressed MAGE-A10 mRNA in the primary lesions. However, the relationship between ATBF1 and MAGE genes and AFP expression is still unknown. Taken together, these findings suggested the aggressive nature of AFP-producing stomach cancer accompanied with MAGE-A10 gene expression.

The function of MAGE family genes and proteins has not been clearly elucidated. In the literature, MAGE-A1, -A2, -A3, -A5, -A6 and -A12 proteins were reported to act as oncoproteins (Yang et al, 2007), whereas MAGE-A4 protein was shown to act as an oncosuppressor protein (Peikert et al, 2006). MAGE-A3 mRNA expression was an independent poor prognostic marker in adenocarcinoma of the lung (Gure et al, 2005). On the other hand, MAGE-A4 mRNA expression correlated with a good clinical outcome in non-small-cell lung cancer (Yoshida et al, 2006). Based on our results, MAGE-A10 gene may participate in tumour progression as an oncoprotein, although further analysis is needed.

In spite of significantly high concordance between MAGE-A protein expression by $6 \mathrm{C} 1$ and MAGE-A 10 gene expression by ISH in our study, 11 cases $(29.7 \%)$ out of 37 patients with positive MAGE-A10 mRNA were negative for 6C1. Wang et al (2004) reported that expression of NY-ESO-1 protein was lower than that of NY-ESO-1 mRNA detected by RT-PCR. It was speculated that immunohistochemical staining could not detect low-level NY-ESO-1 protein expression. Intranuclear substances that are immunohistochemically stained with the $6 \mathrm{C} 1$ antibody reflect the MAGE-A10 protein (Rimoldi et al, 1999). In fact, our results showed that both the nucleus and cytoplasm of the tumour cells were stained in most 6C1-positive cases. We assume that this discrepancy is mainly caused by the differences in sensitivity and specificity between the two detection systems and target sites of the sequence for a cRNA probe generated by PCR and the $6 \mathrm{C} 1$ monoclonal antibody.

The HLA-A2/MAGE-A10 $254-262$ peptide is a good target for active immunotherapy of malignant tumours such as melanoma, hepatocellular carcinoma and lung cancer (Dutoit et al, 2001; Bricard et al, 2005; Groeper et al, 2006). Dutoit et al (2001) reported that only CTL could lyse MAGE-A10-expressing tumour cells. In our experiments, MAGE-A10 expression was associated with an advanced stage of stomach cancer. High incidence of 
MAGE-A10 gene expression was observed in both primary and metastatic lesions in hepatic metastasised patients. Thus, the results of this study suggest that MAGE-A10 is a possible candidate target in active immunotherapy for advanced stomach cancer. Clinical trials of dendritic cell vaccine therapy using HLA-A2/ MAGE-A10 $254-262$ peptide have been conducted (Chianese-Bullock et al, 2005; Davis et al, 2006). In such an active immunotherapy, the first step is the selection of patients suitable for the treatment.
The patients should be selected using immunohistochemical analysis with $6 \mathrm{C} 1$ and assessment of MAGE-A10 gene expression using highly sensitive ISH.

In summary, we clarified the role of MAGE-A10 gene expression on tumour progression, especially liver metastasis in patients with stomach cancer. Based on our methods, it could be possible to select the patients for active immunotherapy using the MAGE-A10 peptide.

\section{REFERENCES}

Adachi Y, Tsuchihashi J, Shiraishi N, Yasuda K, Etoh T, Kitano S (2003) AFP-producing gastric carcinoma: multivariate analysis of prognostic factors in 270 patients. Oncology 65: 95-101

Alves PMS, Lévy N, Bouzourene H, Viatte S, Bricard G, Ayyoub M, Vuilleumier H, Givel JR, Halkic N, Speiser DE, Romero P, Lévy F (2007) Molecular and immunological evaluation of the expression of cancer/ testis gene products in human colorectal cancer. Cancer Immunol Immunother 56: 839-847

Amemiya H, Kono K, Mori Y, Takahashi A, Ichihara F, Iizuka H, Sekikawa T, Matsumoto Y (2005) High frequency of c-Met expression in gastric cancer producing alpha-fetoprotein. Oncology 59: 145-151

Ayyoub M, Rimoldi D, Guillaume P, Romero P, Cerottini JC, Valmori D, Speiser D (2003) Tumor-reactive, SSX-2-specific CD8+ T cells are selectively expanding during immune responses to antigen-expressing tumors in melanoma patients. Cancer Res 63: 5601-5606

Bricard G, Bouzourene H, Martinet O, Rimoldi D, Halkic N, Gillet M, Chaubert P, MacDonald HR, Romero P, Cerottini J, Speiser DE (2005) Naturally acquired MAGE-A10- and SSX-2-specific CD8+ T cell responses in patients with hepatocellular carcinoma. J Immunol 174: $1709-1716$

Chianese-Bullock KA, Pressley J, Garbee C, Hibbitts S, Murphy C, Yamshchikov G, Petroni GR, Bissonette EA, Neese PY, Grosh WW, Merrill P, Fink R, Woodson EM, Wiernasz CJ, Patterson JW, Slingluff CL (2005) MAGE-A1-, MAGE-A10-, and gp100-derived peptides are immunogenic when combined with granulocyte-macrophage colonystimulating factor and montanide ISA-51 adjuvant and administered as part of multipeptide vaccine for melanoma. J Immunol 174: 3080-3086

Cho YG, Son JH, Kim CJ, Lee YS, Kim SY, Nam SW, Lee JY, Park WS (2007) Genetic alterations of the ATBF1 gene in gastric cancer. Clin Cancer Res 13: $4355-4359$

D’Angelica M, Gonen M, Brennan MF, Turnbull AD, Bains M, Karpeh MS (2004) Patterns of initial recurrence in completely resected gastric adenocarcinoma. Ann Surg 240: 808-816

Davis ID, Chen Q, Morris L, Quirk J, Stanley M, Tavarnesi ML, Parente P Cavicchiolo T, Hopkins W, Jackson H, Dimopolos N, Tai TY, MacGregor D, Browning J, Svobodova S, Caron D, Maraskovsky E, Old LJ, Chen W, Cebon J (2006) Blood dendritic cells generated with Flt3 ligand and CD40 ligand prime $\mathrm{CD}^{+} \mathrm{T}$ cells efficiently in cancer patients. J Immunother 29: $499-511$

De Plaen E, Arden K, Traversari C, Gaforio JJ, Szikora JP, De Smet C, Brasseur F, van der Bruggen $P$, Lethé B, Lurquin C, Brasseur R, Chomez P, De Backer O, Cavenee W, Boon T (1994) Structure, chromosomal localization, and expression of 12 genes of the MAGE family. Immunogenetics 40: $360-369$

Dicken BJ, Bigam DL, Cass C, Mackey JR, Joy AA, Hamilton SM (2005) Gastric adenocarcinoma: review and considerations for future directions. Ann Surg 241: 27-39

Dutoit V, Rubio-Godoy V, Dietrich PY, Quiqueres AL, Schnuriger V, Rimoldi D, Liénard D, Speiser D, Guillaume P, Batard P, Cerottini JC, Romero P, Valmori D (2001) Heterogeneous T-cell response to MAGE-A10 $254-262$ : high activity-specific cytolytic $\mathrm{T}$ lymphocytes show superior antitumor activity. Cancer Res 61: 5850-5856

Dutoit V, Taub RN, Papadopoulos KP, Talbot S, Keohan ML, Brehm M, Gnjatic S, Harris PE, Bisikirska B, Guillaume P, Cerottini JC, Hesdorffer CS, Old LJ, Valmori D (2002) Multiepitope CD8+ T cell response to an NY-ESO-1 peptide vaccine results in imprecise tumor targeting. J Clin Invest 110: $1813-1822$

Groeper C, Gambazzi F, Zajac P, Bubendorf L, Adamina M, Rosenthal R, Zerkowski HR, Heberer M, Spagnoli GC (2006) Cancer/testis antigen expression and specific cytotoxic T lymphocyte responses in non small cell lung cancer. Int J Cancer 120: 337-343
Gure AO, Chua R, Williamson B, Gonen M, Ferrera CA, Gnjatic S, Ritter G, Simpson AJG, Chen YT, Old LJ, Altorki NK (2005) Cancer-testis genes are coordinately expressed and are markers of poor outcome in nonsmall cell lung cancer. Clin Cancer Res 11: 8055-8062

Honda T, Tamura G, Waki T, Kawata S, Terashima M, Nishizuka S, Motoyama T (2004) Demethylation of MAGE promoters during gastric cancer progression. Br J Cancer 90: 838-843

Huang LQ, Brasseur F, Serrano A, Plaen ED, Bruggen P, Boon T, Pel AV (1999) Cytolytic $\mathrm{T}$ lymphocytes recognize an antigen encoded by MAGE-A10 on a human melanoma. J Immunol 162: 6849-6854

Inoue $\mathrm{H}$, Mori $\mathrm{M}$, Honda $\mathrm{M}, \mathrm{Li}$ J, Shibuta K, Mimori K, Ueo H, Akiyoshi T (1995) The expression of tumor-rejection antigen 'MAGE' genes in human gastric carcinoma. Gastroenterology 109: 1522-1525

Inoue M, Tsugane S (2005) Epidemiology of gastric cancer in Japan. Postgrad Med J 81: 419-424

Japanese Gastric Cancer Association (1998) Japanese Classification of Gastric Carcinoma - 2nd English edition. Gastric Cancer 1: 10-24

Jiang SX, Kameya T, Asamura H, Umezawa A, Sato Y, Shinada J, Kawakubo Y, Igarashi T, Nagai K, Okayasu I (2004) hASH1 expression is closely correlated with endocrine phenotype and differentiation extent in pulmonary neuroendocrine tumors. Mod Pathol 17: 222-229

Jung EJ, Kim MA, Lee HS, Yang HK, Lee YM, Lee BL, Kim WH (2005) Expression of family A melanoma antigen in human gastric carcinoma. Anticancer Res 25: 2105-2111

Katano M, Nakamura M, Morisaki T, Fujimoto K (1997) Melanoma antigen-encoding gene-1 expression in invasive gastric carcinoma: correlation with stage of disease. J Surg Oncol 64: 195-201

Kataoka H, Miura Y, Joh T, Seno K, Tada T, Tamaoki T, Nakabayashi H, Kawaguchi M, Asai K, Kato T, Itoh M (2001) Alpha-fetoprotein producing gastric cancer lacks transcription factor ATFB1. Oncogene 20: $869-873$

Li J, Yang Y, Fujie T, Tanaka T, Mimori K, Haraguchi M, Ueo H, Mori M, Akiyoshi T (1997) Expression of the MAGE-gene family in human gastric carcinoma. Anticancer Res 17: 3559-3563

Peikert T, Specks U, Farver C, Erzurum SC, Comhair SA (2006) Melanoma antigen A4 is expressed in non-small cell lung cancer and promotes apoptosis. Cancer Res 66: $4693-4700$

Peng JR, Chen HS, Mou DC, Cao J, Cong X, Qin LL, Wei L, Leng XS, Wang Y, Chen WF (2005) Expression of cancer/testis (CT) antigens in Chinese hepatocellular carcinomas and its correlation with clinical parameters. Cancer Lett 219: 223-323

Rimoldi D, Salvi S, Reed D, Coulie P, Jongeneel VC, De Plaen E, Brasseur F, Rodriguez AM, Boon T, Cerottini JC (1999) cDNA and protein characterization of human MAGE-10. Int J Cancer 82: $901-907$

Rimoldi D, Salvi S, Schultz-Thater E, Spagnoli GC, Cerottini JC (2000) Anti-MAGE-3 antibody 57B and anti-MAGE-1 antibody $6 \mathrm{C} 1$ can be used to study different proteins of the MAGE-A family. Int J Cancer 86: $749-751$

Sadanaga N, Nagashima H, Tahara K, Yoshikawa Y, Mori M (1999) The heterogeneous expression of MAGE-A3 protein: difference between primary lesions and metastatic lymph nodes in gastric carcinoma. Oncol Rep 6: $975-977$

Sarela AI, Miner TJ, Karpeh MS, Coit DG, Jaques DP, Brennan MF (2006) Clinical outcome withlaparoscopic stage M1, unresected gastric adenocarcinoma. Ann Surg 243: $189-195$

Siewert JR, Böttcher K, Stein HJ, Roder JD (1998) Relevant prognostic factors in gastric cancer. Ten-year results of the German gastric cancer study. Ann Surg 228: 449-461

Tanizaki Y, Sato Y, Oka H, Utsuki S, Kondo K, Miyajima Y, Nagashio R, Fujii K (2006) Expression of autocrine motility factor mRNA is a poor prognostic factor in high-grade astrocytoma. Pathol Int 56: 510-515 
Wang Y, Wu XJ, Zhao AL, Yuan YH, Chen YT, Jungbluth AA, Gnjatic S, Santiago D, Ritter G, Chen WF, Old LJ, Ji JF (2004) Cancer/testis antigen expression and autologous humorial immunity to NY-ESO-1 in gastric cancer. Cancer Immun 4: 11

Yang B, O’Herrin S, Wu J, Reagan-Shaw S, Ma Y, Nihal M, Longley BJ (2007) Select cancer testis antigens of MAGE-A, -B, and -C families are expressed in mast cell lines and promote cell viability in vitro and in vivo. J Invest Dermatol 127: 267-275
Yoshida N, Abe H, Ohkuni T, Wakita D, Sato M, Noguchi D, Miyamoto M, Morikawa T, Kondo S, b Ikeda H, Nishimura T (2006) Expression of the MAGE-A4 and NY-ESO-1 cancer-testis antigens and T cell infiltration in non-small cell lung carcinoma and their prognostic significance. Int $J$ Oncol 28: $1089-1098$

Yoshikawa M, Takayasu N, Hashimoto A, Sato Y, Tamaki R, Tsukamoto H, Kobayashi H, Noda S (2007) The serine racemase mRNA is predominantly expressed in rat neurons. Arch Histol Cytol 70: 127-134 